\title{
Removal of hexavalent chromium using coffee husk
}

\author{
N. Ahalya
}

Energy \& Wetlands Research Group, Centre for Ecological Sciences, Indian Institute of Science, Bangalore 560 012, India

Email: cestvr@ces.iisc.ernet.in_Email: ahalya@ces.iisc.ernet.in

\section{R.D. Kanamadi}

Department of Zoology, Karnataka University,

Dharwad, India

Email: ravishankar.kanamadi@yahoo.com

\author{
T.V. Ramachandra* \\ Energy \& Wetlands Research Group, \\ Centre for Ecological Sciences, \\ Indian Institute of Science, \\ Bangalore 560 012, India; \\ Centre for Sustainable Technologies, \\ Indian Institute of Science, India \\ Email: energy@ces.iisc.ernet.in \\ *Corresponding author
}

\begin{abstract}
The potential to remove chromium(VI) from aqueous solutions through biosorption using coffee husk was investigated. The effects of $\mathrm{pH}$, contact time, initial concentration and adsorbent dosage on the adsorption of $\mathrm{Cr}(\mathrm{VI})$ were studied. The data obeyed Langmuir and Freundlich adsorption isotherms. The Langmuir adsorption capacity was found to be $44.95 \mathrm{mg} / \mathrm{g}$. The Freundlich constants $K_{\mathrm{f}}$ and $n$ were $1.027\left[\mathrm{mg} / \mathrm{g}(1 / \mathrm{mg})^{n}\right]$ and 1.493 , respectively. Desorption studies indicated the removal of $60 \%$ of the hexavalent chromium. Infrared spectral studies revealed the presence of functional groups, such as hydroxyl and carboxyl groups, on the surface of the biomass, which facilitates biosorption of $\mathrm{Cr}(\mathrm{VI})$.
\end{abstract}

Keywords: chromium(VI); coffee husk; low-cost biosorbent; adsorption; infrared analysis.

Reference to this paper should be made as follows: Ahalya, N., Kanamadi, R.D. and Ramachandra, T.V. (200X) 'Removal of hexavalent chromium using coffee husk', Int. J. Environment and Pollution, Vol. X, No. Y, pp.xx-xx.

Biographical notes: N. Ahalya has obtained $\mathrm{PhD}$ from the Department of Zoological Sciences, Karnatak University. She has published over 14 research papers and three books. She is a postdoctoral fellow at Energy and Wetlands Research Group, CES, IISc. 


\section{N. Ahalya et al.}

R.D. Kanamadi has obtained $\mathrm{PhD}$ from Karnatak University. The first report on acoustic communication in Indian anurans was published in 1992 by him. He has worked on the analysis of advertisement calls of frogs, courtship, nesting behaviour, vocal interaction and territoriality and fighting behaviour in some anurans and reported for the first time parental care and direct development in Indian frogs. He has also worked in the field of toxicology which includes the effect of the mercurial fungicide Emisan, phospatic deflocculant sodium tripolyphosphate, Endosufan and biocide Kathon on the developmental stages of the Zebra fish. Presently he is working in the field of environmental biology, especially on zooplankton diversity, water quality/trophic status and biosorption of heavy metals using some low-cost absorbents such as the husk of Bengal gram, Tur dal, coffee and tamarind pod shells.

T.V. Ramachandra has obtained $\mathrm{PhD}$ in Ecology and Energy from the Indian Institute of Science. His research area includes energy, ecology, climate change, ecosystems and environment, conservation, restoration and management of ecosystems, environmental management, GIS, remote sensing, regional planning and decision support systems, wetlands. During the past 10 years he has established an active school of research in the area of energy and environment. He teaches principles of remote sensing, digital image processing and natural resources management. He has developed environmental engineering courses for a distance education programme, which has been offered since 2004. He has published over 182 research papers as well as 14 books. He is a fellow of Institution of Engineers (India), Fellow, IEE (UK), a senior member of IEEE (USA) and of many similar institutions.

\section{Introduction}

Chromium is an essential nutrient for plant and animal metabolism. However, the increasing accumulation of chromium in the environment from industrial outputs has caused great concern. Chromium-contaminated wastewaters can originate from dyes and pigment manufacturing, wood preserving, electroplating and leather tanning. Chromium exists in +3 and +6 oxidation states, as all other oxidation states are not stable in aqueous solutions. Both valences of chromium are potentially harmful (Dakiky et al., 2002). Hexavalent chromium which is primarily present in the form of chromate $\left(\mathrm{CrO}_{4}{ }^{2-}\right)$ and dichromate $\left(\mathrm{Cr}_{2} \mathrm{O}_{7}{ }^{2-}\right)$ poses significantly higher levels of toxicity than the other valency states (Sharma and Forster, 1995).

Conventional methods for removing $\mathrm{Cr}(\mathrm{VI})$ ions from industrial wastewater include reduction (Kim et al., 2002), reduction followed by chemical precipitation (Ozer et al., 1997), adsorption on activated carbon (Lotfi and Adhoum, 2002), solvent extraction (Mauri et al., 2001), freeze separation, reverse osmosis (Padilla and Tavani, 1999), ion exchange (Rengaraj et al., 2003) and electrolytic methods (Namasivayam and Yamuna, 1995). These methods have found limited application because they often involve high capital and operational costs. Adsorption is an effective and versatile method for removing chromium. Natural materials that are available in large quantities or certain waste products from industrial or agricultural operations may have potential as 


\section{Removal of hexavalent chromium using coffee husk}

inexpensive sorbents. Most of the low-cost sorbents have the limitation of low sorptive capacity and thereby for the same degree of treatment, it generates more solid waste (pollutant-laden sorbent after treatment), which poses disposal problems. Therefore, there is a need to explore low-cost sorbents having high contaminant sorption.

Fly ash from thermal power plant (Panday et al., 1984), waste slurry from a fertiliser plant (Srivastava et al., 1989) and $\mathrm{Fe}(\mathrm{III}) / \mathrm{Cr}$ (III) hydroxide obtained from the petrochemical industry (Namasivayam and Ranganathan, 1993), blast furnace flue dust (Patnaik and Das, 1995) and photo film waste sludge (Selvaraj et al., 1997) have been examined for the removal of hexavalent chromium. The adsorption of $\mathrm{Cr}(\mathrm{VI})$ on bituminous coal (Rawat and Singh, 1992), sphagnum peat moss (Sharma and Forster, 1993), coconut husks and palm pressed fibres (Tan et al., 1993), sawdust, sugarcane bagasse, sugarbeet pulp and maize cob (Sharma and Forster, 1994) has been reported. A thorough literature survey indicated that coffee husk has not been used as an adsorbent thus far. The objective of the present study was to explore the feasibility of using coffee husk to remove hexavalent chromium from aqueous solutions. The effects of $\mathrm{pH}$, contact time, biomass concentration and adsorption equilibrium were investigated.

\section{Materials and methods}

The coffee husk was collected from coffee processing unit. The husk was washed and boiled to remove colour and impurities. The biomass was then air dried at $105{ }^{\circ} \mathrm{C}$ for 24 hours and the adsorbent thus processed was used in its original piece size. A stock solution containing $1000 \mathrm{mg} / \mathrm{l}$ of $\mathrm{Cr}(\mathrm{VI})$ was prepared using potassium dichromate in distilled water. All the chemicals used were of analytical grade. Batch mode experiments were conducted by agitating $1 \mathrm{~g}$ of the adsorbent with $100 \mathrm{ml}$ of $\mathrm{Cr}(\mathrm{VI})$ solution of desired concentration at $\mathrm{pH}$ 2. The adsorbent was separated using Whatman No.1 filter paper and the supernatant was analysed spectrophotometrically using 1,5-diphenylcarbazide (APHA, 1985). To study the effect of $\mathrm{pH}$, it was varied between 2 and 7 at different initial metal concentrations. The $\mathrm{pH}$ was adjusted using $0.1 \mathrm{~N} \mathrm{NaOH}$ and $0.1 \mathrm{~N} \mathrm{HCl}$. The effect of adsorbent dosage was studied by varying the adsorbent from $0.5 \mathrm{~g}$ to $6 \mathrm{~g}$ at various initial metal concentrations at $\mathrm{pH} 2$. The desorption studies were carried out by filtering the $\mathrm{Cr}(\mathrm{VI})$ loaded adsorbent from solution, washing gently with distilled water to remove unadsorbed $\mathrm{Cr}(\mathrm{VI})$ and agitating the metal loaded adsorbent with distilled water and varying concentrations of $\mathrm{NaOH}$ and $\mathrm{HCl}$. Infrared spectroscopic studies of coffee husk before and after treatment with $\mathrm{Cr}(\mathrm{VI})$ was carried out to determine the functional groups responsible for adsorption using a Fourier Transform Infrared Spectrometer (FTIR).

\section{Results and discussion}

\subsection{Characteristics of the adsorbent}

The carbon, hydrogen and nitrogen percentages of the coffee husk were 45.33, 6.21 and 0.63 , respectively. A relatively larger percentage of hydrogen in comparison to nitrogen compounds indicates that carbon-hydrogen groups might be available for adsorption of 


\section{N. Ahalya et al.}

metals. The relatively low percentage of nitrogen shows that very less percentage of protein might be present in the husks. This is advantageous over protein-rich adsorbents since proteinous materials are likely to putrefy under moist conditions.

\subsection{Effect of agitation time and initial Cr(VI) concentration on Cr(VI) adsorption}

The effect of agitation time for various initial concentrations was studied (Figure 1). The percentage adsorption of $\mathrm{Cr}(\mathrm{VI})$ increased with an increase in agitation time and the equilibrium time varied for different $\mathrm{Cr}(\mathrm{VI})$ concentrations. The time required to attain equilibrium for 10 and $20 \mathrm{mg} / \mathrm{l} \mathrm{Cr}(\mathrm{VI})$ concentration was 120 minutes and 50 and $100 \mathrm{mg} / \mathrm{l} \mathrm{Cr}(\mathrm{VI})$ attained equilibrium at 180 minutes. The maximum percentage adsorption was $99 \%, 98 \%, 96 \%$ and $75 \%$ respectively for initial $\mathrm{Cr}(\mathrm{VI})$ concentrations of $10,20,50$ and $100 \mathrm{mg} / \mathrm{l}$.

Figure 1 Effect of agitation time and initial Cr(VI) concentration $(\bullet, 10 \mathrm{mg} / 1 ; \mathbf{m}, 20 \mathrm{ppm}$;

-, $50 \mathrm{mg} / \mathrm{l} ; \boldsymbol{\Delta}, 100 \mathrm{mg} / \mathrm{l}$ ) on $\mathrm{Cr}(\mathrm{VI})$ removal (adsorbent dose: $1 \mathrm{~g} / 100 \mathrm{ml} ; \mathrm{pH} 2.0$ )

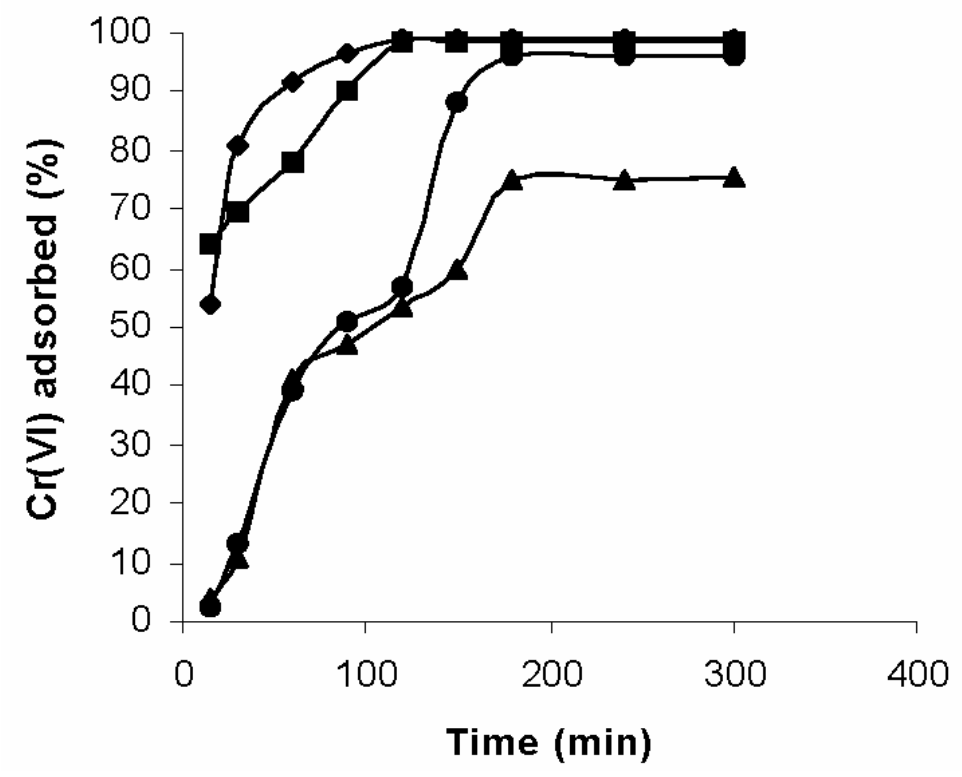

\subsection{Effect of adsorbent dose on adsorption}

The percentage adsorption of $\mathrm{Cr}(\mathrm{VI})$ was studied by increasing adsorbent dose from $50 \mathrm{mg}$ to $6 \mathrm{~g}$ for $100 \mathrm{ml}$ of $\mathrm{Cr}(\mathrm{VI})$ concentration of 10, 20, 50 and $100 \mathrm{mg} / \mathrm{l}$ (Figure 2). The results indicated that the percentage of $\mathrm{Cr}(\mathrm{VI})$ adsorbed increased with an increase in adsorbent dosage for all $\mathrm{Cr}(\mathrm{VI})$ concentrations. The increase in percentage adsorption with increase in adsorbent dosage is due to the increase in the number of adsorption sites (Sharma and Forster, 1993; Selvaraj et al., 1997). 
Removal of hexavalent chromium using coffee husk

Figure 2 Effect of adsorbent dose on $\mathrm{Cr}(\mathrm{VI})$ adsorption at various $\mathrm{Cr}(\mathrm{VI})$ concentrations $(\bullet, 10 \mathrm{mg} / \mathrm{l} ; \mathbf{m}, 20 \mathrm{ppm} ; \bullet, 50 \mathrm{mg} / \mathrm{l} ; \boldsymbol{\Lambda}, 100 \mathrm{mg} / \mathrm{l}$; agitation time 180 minutes; initial $\mathrm{pH}$ 2.0)

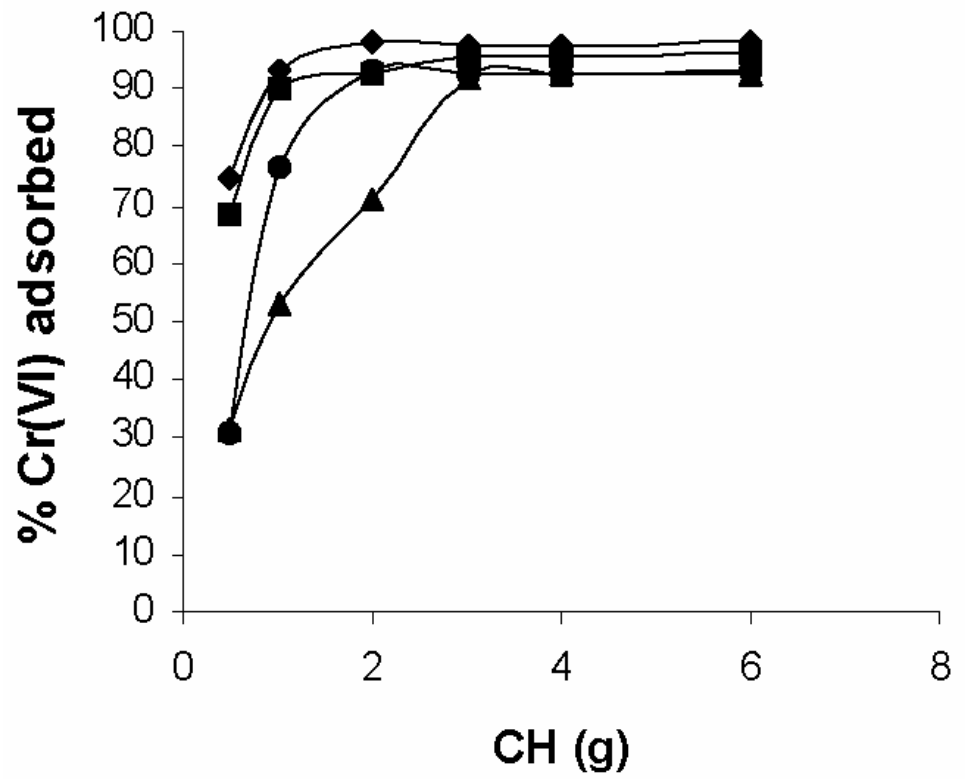

\subsection{Effect of $p H$}

The $\mathrm{pH}$ of the solution is an important factor that controls the uptake of $\mathrm{Cr}(\mathrm{VI})$. The experimental results revealed that the percentage adsorption increased as the $\mathrm{pH}$ was lowered and reached $99 \%, 98 \%$ and $96 \%$ respectively for 10,20 and $50 \mathrm{mg} / \mathrm{l} \mathrm{Cr}$ (VI) concentrations. When the $\mathrm{pH}$ was increased above 2, the per cent removal decreased (Figure 3). Similar results were reported by Donmez and Aksu (2002), Dakiky et al. (2002), Selvaraj et al. (2003), Yu et al. (2003), Ucun et al. (2002), Hu et al. (2003) and Gupta et al. (2001). The high adsorption of $\mathrm{Cr}(\mathrm{VI})$ can be explained by the species of chromium and the adsorbent surface. At acidic $\mathrm{pH}$, the predominant species of $\mathrm{Cr}(\mathrm{VI})$ are $\mathrm{Cr}_{2} \mathrm{O}_{7}{ }^{2-}, \mathrm{HCrO}_{4}^{-}$and $\mathrm{CrO}_{4}{ }^{2-}$. Under acidic conditions, the surface of the adsorbent becomes protonated and attracts anionic species of $\mathrm{Cr}(\mathrm{VI})$. As the $\mathrm{pH}$ is increased above the zeta potential of the adsorbent, there is a reduction in the electrostatic attraction between the $\mathrm{Cr}(\mathrm{VI})$ species and the adsorbent surface, with a consequent decrease in percentage adsorption.

\subsection{Adsorption isotherms}

The Langmuir isotherm was applied to the present study to estimate the adsorption capacity of coffee husk. It is valid for monolayer adsorption onto a surface containing a finite number of identical sites (Langmuir, 1918). The linear plots of $C_{\mathrm{eq}} / q$ vs $C_{\mathrm{eq}}$ for $\mathrm{Cr}(\mathrm{VI})$ show that adsorption follows the Langmuir adsorption model (Figure 4). $q_{\max }$ and $b$ were determined from the slope and the intercept of the plot to be $44.95 \mathrm{mg} / \mathrm{g}$ and $0.01 \mathrm{l} / \mathrm{mg}$, respectively. 
N. Ahalya et al.

Figure 3 Effect of $\mathrm{pH}$ on $\mathrm{Cr}(\mathrm{VI})$ adsorption at different initial $\mathrm{Cr}(\mathrm{VI})$ concentrations $(\bullet, 10 \mathrm{mg} / \mathrm{l}, \mathbf{\square}, 20 \mathrm{ppm} ; \bullet, 50 \mathrm{mg} / \mathrm{l} ; \boldsymbol{\Lambda}, 100 \mathrm{mg} / \mathrm{l})$

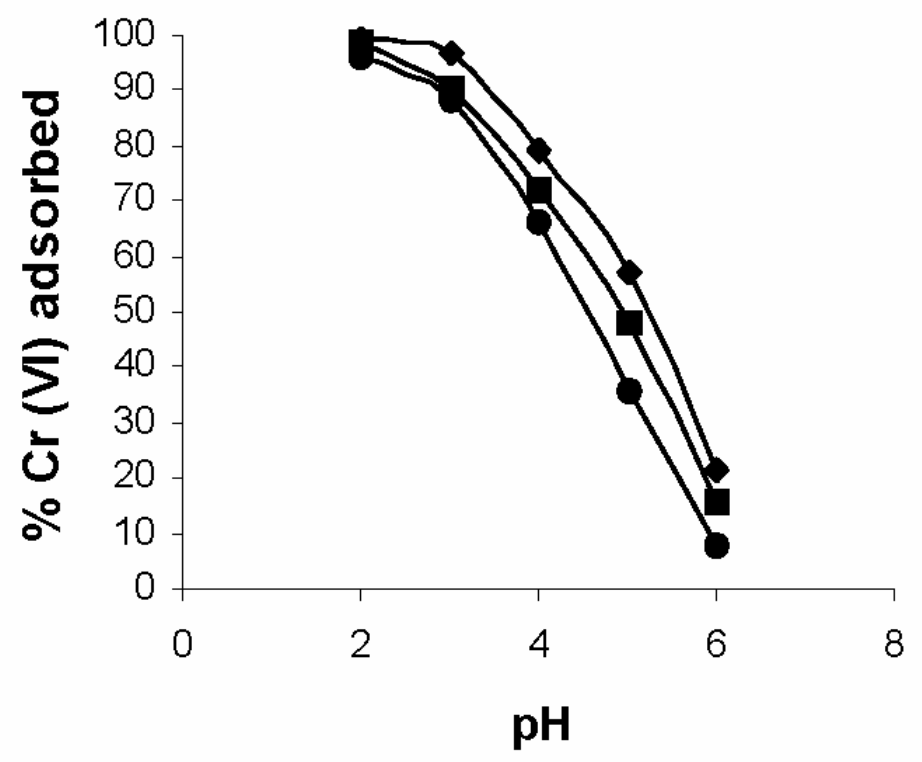

Figure 4 Langmuir plot for $\mathrm{Cr}(\mathrm{VI})$ adsorption (agitation time 180 minutes; initial pH 2.0) (see online version for colours)

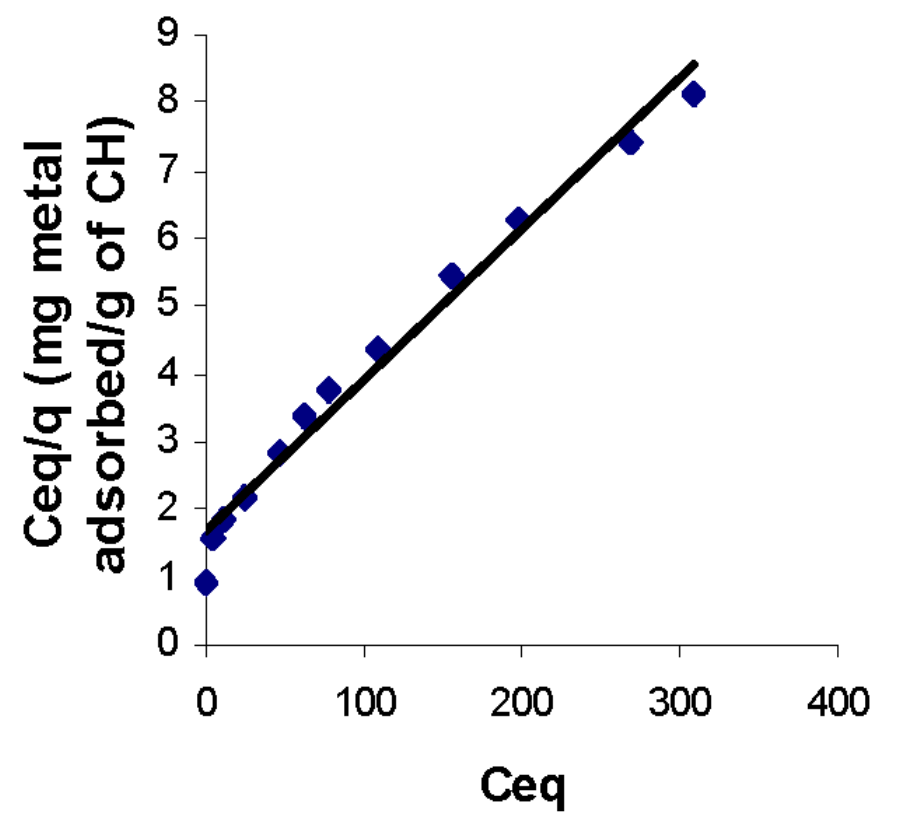




\section{Removal of hexavalent chromium using coffee husk}

The Freundlich adsorption isotherm (Freundlich, 1907) was also applied for the adsorption of $\mathrm{Cr}(\mathrm{VI})$ onto coffee husk. Linear plots of In $C_{\mathrm{eq}}$ vs In $q$ show that the adsorption of metal ions onto the coffee husk follows the Freundlich isotherm model (Figure 5). Freundlich constants $K_{\mathrm{f}}$ and $n$ were found to be $1.02 \mathrm{mg} / \mathrm{g}$ and 1.49 , respectively. It has been shown by McKay et al. (1982) that $n$ values between 1 and 10 indicate beneficial adsorption.

Figure 5 Freundlich plot for $\mathrm{Cr}(\mathrm{VI})$ adsorption (initial $\mathrm{pH}$ : 2.0; agitation time 180 minutes) (see online version for colours)

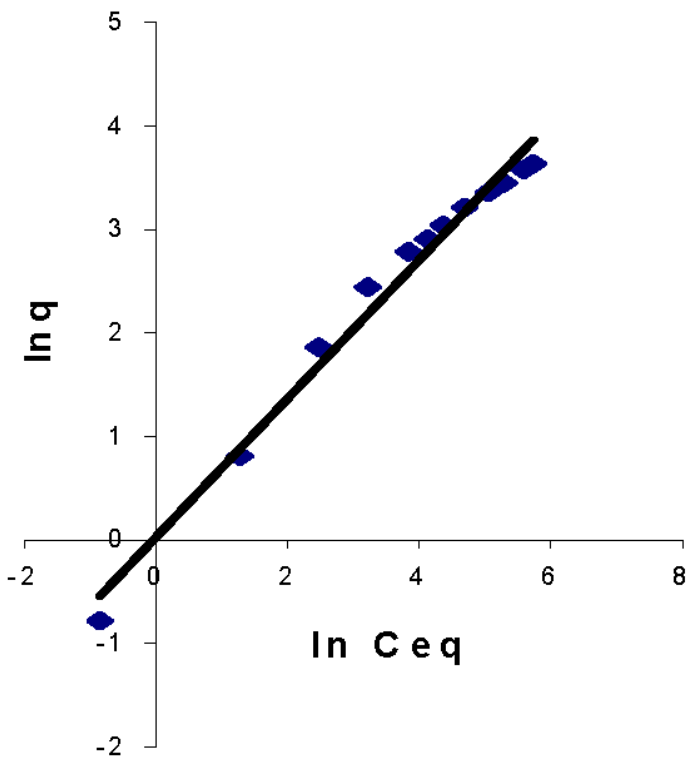

The adsorption data obeyed both Freundlich and Langmuir models exhibiting heterogeneous surface conditions and monolayer adsorption (Lee et al., 1995). The favourable nature of adsorption can be expressed in terms of a dimensionless parameter $R_{\mathrm{L}}$ given by the equation

$$
R_{\mathrm{L}}=1 /\left(+b C_{0}\right)
$$

where $b$ is the Langmuir constant and $C_{0}$ is the initial concentration of $\mathrm{Cr}(\mathrm{VI})$. All $R_{\mathrm{L}}$ values obtained using equation (1) for $\mathrm{Cr}(\mathrm{VI})$ adsorption are greater than zero and less than unity showing favourable adsorption of $\mathrm{Cr}(\mathrm{VI})$ onto coffee husk.

\subsection{Comparison with other adsorbents}

The comparison of adsorbent capacity of coffee husk with other materials reported in literature is given in Table 1. The sorption capacity of coffee husk is higher than adsorbents from various industrial and low-cost adsorbents. 


\section{N. Ahalya et al.}

Table 1 Comparison of adsorption capacity of Cr (VI) with other adsorbents

\begin{tabular}{lll}
\hline Biosorbent & $C r(V I) m g / g$ & Reference \\
\hline Distillery sludge & 5.7 & Selvaraj et al., 2003 \\
Exhausted coffee & 1.42 & Orhan and Büyügüngör, 1993 \\
Nut shell & 1.47 & Orhan and Büyügüngör, 1993 \\
Sawdust & $10.1,16.05,4.44$ & Bryant et al., 1992; Dikshit, 1989; Zarraa, 1995 \\
Walnut shell & 1.5 & Orhan and Büyügüngör, 1993 \\
Waste tea & 1.63 & Orhan and Büyügüngör, 1993 \\
Irish sphagnum moss & $119.0,43.9$ & Sharma and Forster 1993, 1995 \\
peat & & \\
Iron (III) hydroxide & 0.47 & Namasivayam and Rangnathan, 1993 \\
Blast furnace slag & 7.5 & Srivastava et al., 1997 \\
Activated red mud & 1.6 & Pradhan et al., 1999 \\
Rice husk carbon & 45.6 & Srinivasan et al., 1988 \\
Waste tyre & 58.48 & Hamadi et al., 2001 \\
Olive cake & 33.44 & Dakiky et al., 2002 \\
Pine needles & 21.50 & Dakiky et al., 2002 \\
Wool & 41.15 & Dakiky et al., 2002 \\
Coffee husk & 44.95 & This study \\
\hline
\end{tabular}

\subsection{Infrared spectral analysis}

The FTIR spectral analysis shows that several functional groups are available on the surface of coffee husk for binding $\mathrm{Cr}(\mathrm{VI})$ ions (Table 2).

Table 2 Wavelengths corresponding to their respective functional groups

\begin{tabular}{ll}
\hline Wavelength $\left(\mathrm{cm}^{-1}\right)$ & Functional group \\
\hline 3431 & $-\mathrm{OH}$ \\
2925 & $-\mathrm{CH}$ \\
1726 & $\mathrm{C}=\mathrm{O}$ \\
1652 & $\mathrm{C}=\mathrm{C}$ \\
1430 & $-\mathrm{COO}$ \\
\hline
\end{tabular}

\subsection{Desorption studies}

Adsorption process can either be physisorption (physical bonding) or chemisorption (chemical bonding) or combination of both. If the adsorption is by physical bonding then the loosely bound metal ion can be easily desorbed with distilled water in most of the cases. However, if the mode of sorption is by chemical bonding or ion exchange or combination of both, then desorption can be effected by stronger desorbents like acid or alkali solutions. Distilled water ( $\mathrm{pH}$ 6.9) was used to desorb $\mathrm{Cr}(\mathrm{VI})$ from $\mathrm{Cr}(\mathrm{VI})$ loaded coffee husk. The results revealed that the $\mathrm{Cr}(\mathrm{VI})$ was not removed from metal-laden biomass. Hence the experiments were conducted with acid and alkali solutions. The $\mathrm{Cr}(\mathrm{VI})$ ions were desorbed with alkali solutions $(\mathrm{NaOH})$ and not with acid 


\section{Removal of hexavalent chromium using coffee husk}

solutions. Figure 6 shows that about $60 \%$ of $\mathrm{Cr}(\mathrm{VI})$ was desorbed using $0.02 \mathrm{M} \mathrm{NaOH}$. From the desorption experimental results it can be concluded that the mode of biosorption of $\mathrm{Cr}(\mathrm{VI})$ on coffee husk was chemisorption. The results of alkali desorption of metal suggests either chemisorption or ion exchange as the possible mechanism of binding between $\mathrm{Cr}(\mathrm{VI})$ and coffee husk. At higher $\mathrm{pH}$, hydroxyl ions may release chromium ions from the adsorbent following an ion exchange mechanism.

Figure 6 Effect of $\mathrm{NaOH}$ concentration on desorption of $\mathrm{Cr}(\mathrm{VI})$

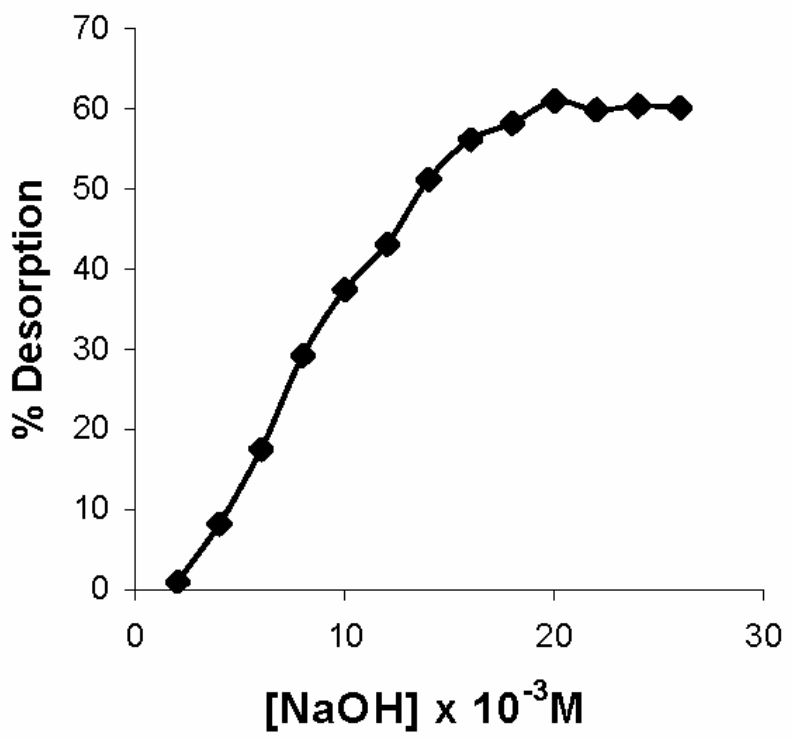

\section{Conclusion}

The experimental results show that coffee husk is an excellent alternative for the removal of $\mathrm{Cr}(\mathrm{VI})$ from aqueous solutions. The biosorption of $\mathrm{Cr}(\mathrm{VI})$ was dependent on $\mathrm{pH}$, contact time, adsorbent dosage and initial metal concentration. Both Langmuir and Freundlich isotherms were followed by the adsorption of $\mathrm{Cr}(\mathrm{VI})$. The infra red spectral analysis showed that the functional groups like carboxyl and hydroxyl ions played an important role in the biosorption of $\mathrm{Cr}(\mathrm{VI})$. As the coffee husk is easily available from coffee processing units, its utility as biosorbent will be economical and be viewed as part of waste management strategy. Containing very less amount of protein $(N=0.63)$, coffee husk is advantageous over the protein-rich algal and fungal biomass projected as metal biosorbents, since proteinous materials are likely to putrefy under moist conditions. Moreover, the desorption experiments show that the metals can be desorbed after adsorption and $\mathrm{Cr}(\mathrm{VI})$ can be recovered. The present adsorbent can be used at an industrial scale to remove chromium ions from the effluents before discharging into the environment. Coffee husk can replace the expensive activated carbon in the adsorption process. Most of the electroplating effluents contain chromium as one of the major contaminant, which can be removed in a cost-effective and efficient manner by coffee husk. 


\section{N. Ahalya et al.}

\section{References}

APHA (1985) Standard Methods for the Estimation of Waste and Wastewater, 16th ed., American Public Health Association, Washington, DC.

Bryant, P.S., Petersen, J.N., Lee, J.M. and Brouns, T.M. (1992) 'Sorption of heavy metals by untreated red Bsawdust', Applied Biochemistry and Biotechnology, Vol. 34/35, pp.777-788.

Dakiky, M., Khami, A., Manassra, A. and Mer'eb, M. (2002) 'Selective adsorption of chromium (VI) in industrial wastewater using low cost abundantly available adsorbents', Advances in Environmental Research, Vol. 6, No. 4, pp.533-540.

Dikshit, V.P. (1989) 'Removal of chromium (VI) by adsorption using sawdust', National Academy of Science Letters, Vol. 12, No. 12, pp.419-421.

Donmez, G. and Aksu, Z. (2002) 'Removal of chromium (VI) from wastewaters by Dunaliella species', Process Biochemistry, Vol. 38, No. 5, pp.751-762.

Freundlich, H. (1907) 'Ueber die adsorption in Loesungen', Zeitschrift fr Physikalische Chemie, Vol. 57, pp.385-470.

Gupta, V.K., Shrivastava, A.K. and Jain, N. (2001) 'Biosorption of chromium (VI) from aqueous solutions by green algae Spirogyra species', Water Research, Vol. 35, No. 17, pp.4079-4085.

Hamadi, N.K., Chen, X.D., Farid, M.M. and Lu, M.G.Q. (2001) 'Adsorption kinetics for the removal of chromium (VI) from aqueous solution by adsorbents derived from used tyres and sawdust', Chemical Engineering Journal, Vol. 84, pp.95-105.

Hu, Z., Lei, L., Li Y. and Ni, Y. (2003) 'Chromium adsorption on high performance activated carbon from aqueous solution', Separation and Purification Technology, Vol. 31, No. 1, pp.13-18.

Kim, S.D., Park, K.S. and Gu, M.B. (2002) 'Toxicity of hexavalent chromium to Daphnia magna: influence of reduction reaction by ferrous iron', Journal of Hazardous Materials, Vol. 93, No. 2, pp.155-164.

Langmuir, I. (1918) 'The adsorption of gases on plane surfaces of glass, mica and platinum', Journal of American Chemical Society, Vol. 40, pp.1361-1403.

Lee, C.K., Low, K.S. and Kek, K.L. (1995) 'The removal of chromium from aqueous solution', Bioresource Technology, Vol. 54, pp.183-189.

Lotfi, M. and Adhoum, N. (2002) 'Modified activated carbon for the removal of copper, zinc, chromium and cyanide from wastewater', Separation and Purification Technology, Vol. 26, Nos. 2-3, pp.137-146.

Mauri, R., Shinnar, R., Amore, M.D., Giordano, P. and Volpe, A. (2001) 'Solvent extraction of chromium and cadmium from contaminated soils', American Institute of Chemical Engineers Journal (AIChE), Vol. 47, No. 2, pp.509-512.

McKay, G., Blair, H.S. and Gardener, J.R. (1982) 'Adsorption of dyes on chitin I. Equilibrium studies', Journal of Applied Polymer Science, Vol. 27, pp.3043-3057.

Namasivayam, C. and Rangnathan, K. (1993) 'Waste Fe (III)/Cr (III) hydroxide adsorbent for the removal of $\mathrm{Cr}$ (VI) from aqueous solution and chromium plating industry wastewater', Environmental Pollution, Vol. 82, pp.255-261.

Namasivayam, C. and Yamuna, R.T. (1995) 'Adsorption of chromium (VI) by a low cost adsorbent: biogas residual slurry', Chemosphere, Vol. 30, No. 3, pp.561-578.

Orhan, Y. and Büyükgüngor, H. (1993) 'The removal of heavy metals by using agricultural wastes', Water Science Technology, Vol. 28, No. 2, pp.247-255.

Ozer, A., Altundogan, H.S., Erdem, M. and Tunmen, F. (1997) 'A study on the Cr (VI) removal from aqueous solutions by steel wool', Environmental Pollution, Vol. 97, Nos. 1-2, pp.107-112. 


\section{Removal of hexavalent chromium using coffee husk}

Padilla, A. and Tavani, E.L. (1999) 'Treatment of an industrial effluent by reverse osmosis', Desalination, Vol. 129, Nos. 1-3, pp.219-226.

Panday, K.K., Prasad, G. and Singh, V.N. (1984) 'Removal of chromium from aqueous solution by adsorption on flyash wollostonite', Journal of Chemical Technology and Biotechnology, Vol. 34, pp.367-374.

Patnaik, L.N. and Das, C.P. (1995) 'Removal of hexavalent chromium by blast furnace fluedust', Indian Journal of Environmental Health, Vol. 37, pp.19-25.

Pradhan, J., Das, S.N. and Thakur, J. (1999) 'Adsorption of hexavalent chromium from aqueous solution by using activated red mud', Journal of Colloidal Interface Science, Vol. 217, pp.137-141.

Rawat, N.S. and Singh, C.D. (1992) 'Removal of Cr (VI) on bituminous coal', Asian Environment, Vol. 14, pp.30-41.

Rengaraj, S., Joo, C.K., Kim, Y. and Yi, J. (2003) 'Kinetics of removal of chromium from water and electronic process wastewater by ion exchange resins: $1200 \mathrm{H}, 1500 \mathrm{H}$ and IRN97H', Journal of Hazardous Materials, Vol. 102, Nos. 2-3, pp.257-275.

Selvaraj, K., Chandramohan, V. and Pattabhi, S. (1997) 'Removal of Cr (VI) from solution and chromium plating industry wastewater using photofilm waste sludge', Indian Journal of Chemical Technology, Vol. 18, pp.641-646.

Selvaraj, K., Manonmani, S. and Pattabhi, S. (2003) 'Removal of hexavalent chromium using distillery sludge', Bioresource Technology, Vol. 89, No. 2, pp.207-211.

Sharma, D.C. and Forster, C.F. (1993) 'Removal of hexavalent chromium using sphagnum moss peat', Water Research, Vol. 27, pp.1201-1208.

Sharma, D.C. and Forster, C.F. (1994) 'A preliminary examinations into the adsorption of hexavalent chromium using low cost adsorbents', Bioresource Technology, Vol. 47, pp.257-264.

Sharma, D.C. and Forster, C.F. (1995) 'Column studies into the adsorption of chromium (VI) using sphagnum moss peat', Bioresource Technology, Vol. 52, pp.261-267.

Srinivasan, K., Balasubramanian, N. and Ramakrishna, T.V. (1988) 'Studies on chromium removal by rice husk carbon', Indian Journal of Environmental Health, Vol. 30, pp.376-387.

Srivastava, S.K., Tyagi, R. and Pant, N. (1989) 'Adsorption of heavy metal ions on carbonaceous material developed from the waste slurry generated in local fertilizer plant', Water Research, Vol. 23, pp.1161-1165.

Srivastava, S.K., Gupta, V.K. and Mohan, D. (1997) 'Removal of Lead and Chromium by activated slag - a blast furnace waste', Journal of Environmental Engineering, Vol. 123, pp.461-468.

Tan, W.T., Ooi, S.T. and Lee, C.K. (1993) 'Removal of Cr (VI) from solution by cocunut husk and palm pressed fiber', Environmental Technology, Vol. 14, p.277.

Ucun, H., Bayhan, Y.K., Kaya, Y., Cakici, A. and Algur, O.F. (2002) 'Biosorption of chromium (VI) from aqueous solution by cone biomass of Pinus sylvestris', Bioresource Technology, Vol. 85, No. 2, pp.155-158.

Yu, L.J., Shukla, S.S., Dorris, K.L., Shukla, A. and Margrave, J.L. (2003) 'Adsorption of chromium from aqueous solutions by maple sawdust', Journal of Hazardous Materials, Vol. B 100, pp.53-63.

Zarraa, M.A. (1995) 'A study on the removal of chromium (VI) from waste solutions by adsorption on to sawdust in stirred vessels', Adsorption Science Technology, Vol. 12, No. 2, pp.129-138. 